\title{
Word order patterns in generic 'zero person' constructions in Finnish: Insights from speech-act participants
}

\author{
Elsi Kaiser*
}

\begin{abstract}
I suggest that seemingly puzzling word-order properties of the Finnish generic zero person construction can be explained if we acknowledge the relevance of speech-act participants (speaker/addressee) for the Finnish version of the EPP. Building on work by Moltmann $(2006,2010)$ on generic one as well as Malamud's work (2012) on the features of one and you, I identify two different kinds of zero person constructions in Finnish, suggest evidence that the two kinds of zeros differ in their featural properties, and propose a refinement to the topicality-based EPP in Finnish that can be used to explain unexpected word order patterns of the zero person construction. This work draws new connections between reference to speechact participants (in particular speaker-related meaning) and word order constraints.
\end{abstract}

Keywords. generic pronouns; impersonal constructions; Finnish; syntax-semantics interface; word order; speech-act participants; speaker; addressee; EPP; zero person

1. Introduction. Standard Finnish has no overt generic pronoun like English one or you, and uses third-person singular verbs with phonologically null subjects to convey generic human reference in the 'zero person' construction. (e.g. Hakulinen \& Karttunen 1973, Holmberg 2010, Vilkuna 1992), (1a,b). The zero person is unacceptable in non-generic, episodic contexts like (1c). (The underscore _ denotes the zero.) (1a,b) are generic and cannot receive a referential (anaphoric) interpretation, as Finnish does not have third-person pro-drop in main clauses. ${ }^{1}$
a. Suomessa _ joutuu usein saunaan. (adapted from Laitinen 2006)
Finland-INE — end-up-3SG often sauna-ILL
'In Finland you/one often end(s) up in the sauna'
b. Jos_asuu Kaliforniassa, _ pääsee nauttimaan merestä.
If — live-3SG California-INE, _ gets-to-PRS-3SG enjoy ocean-ELA
'If you/one live(s) in California, you/one get(s) to enjoy the ocean.
c. * Nyt_ löysi_ kaksi leppäkerttua. (Hakulinen \& Karttunen 1973:164)
Now _ find-PST.3SG two ladybug-PAR
'Now one/you found two ladybugs.'

In this paper I present evidence that the Finnish zero person, in addition to being generic, is also linked to the speech-act participants (speaker, addressee) and exhibits unexpected word order properties which are not fully captured by prior accounts. In particular, I suggest that the word order properties of the Finnish generic zero person construction can be explained once we acknowledge the relevance of speech-act participants for the Finnish EPP. By extending the

\footnotetext{
* Many thanks to Arto Anttila, Anders Holmberg, Lauri Karttunen and Paul Kiparsky for comments on earlier versions of this work, as well as the audience at the 2019 Annual Meeting of the LSA. All errors are my own. Author: Elsi Kaiser, University of Southern California, emkaiser@usc.edu.

${ }^{1}$ Abbreviations used: NOM nominative, ACC accusative, GEN genitive, PAR partitive, ELA elative, ILL illative, ADE adessive, ALL allative, INE inessive, PST past tense, COND conditional, IMP imperative, 1SG first person singular, 3SG third person singular, PX possessive suffix. Infinitival verbs are glossed as 'bare verbs' (not glossed in detail) because the multiple infinitival forms of Finnish are not central for the claims being made in this paper.
} 
analysis of Malamud (2012) for English and German impersonal pronouns, I strive to identify the features that Finnish zero pronouns are built out of, and I suggest that these featural properties capture the otherwise unexpected word order patterns of certain zero person sentences.

1.1 GENERIC REFERENCE. In this paper, I focus on generic sentences of the type shown in (1) and (2). Broadly speaking, there is a lot of crosslinguistic variation in what forms/grammatical devices convey generic meaning of this type, including impersonal pronouns (German man, English one, French on) and 2rd person singular pronouns (you). In this paper, I do not investigate other impersonal constructions such as arbitrary they or impersonal passives.

(2) a. One can see the picture from the entrance. (Moltmann 2006) [British English 'one']

b. You can see the picture from the entrance.

[American English 'you']

The structure of this paper is as follows. In Sections 2 and 3, I discuss the syntactic and semantic properties of the Finnish zero person. In Section 4, I show that the zero person exhibits some unexpected word order properties. In Sections 5 and 6, I sketch out a possible analysis that builds on Malamud (2012)'s work on English one and German man, and Moltmann (2010)'s work on English one. In Section 7, I provide additional evidence in favor of my approach from the expletive sitä (it-PAR) and the proximity adverbial tässä (here-INE).

2. Finnish generic 'zero person': Syntactic properties. This section discusses the syntactic properties of the zero person: It patterns like overt arguments for purposes for case assignment, binds reflexives, and is singular and third person for purposes of morphosyntactic agreement.

2.1 CASE-MARKING. The zero person being phonologically null raises the question of whether it is syntactically realized. However, the zero patterns just like overt arguments for purposes of case assignment. This can be observed by comparing zero person sentences and overt subjects to clearly (syntactically) subjectless sentences such as impersonal passives and imperatives (e.g. Vilkuna 1996). In the zero person sentence in (3a), the object noun is accusative - just like in a sentence with an overt subject (3b). In contrast, in sentences without a nominative, verbagreement-triggering external argument (e.g. passives in $3 \mathrm{c}$ and imperatives in $3 \mathrm{~d}$ ), the patient noun is nominative (e.g. Timberlake 1974, Maling 1993, Kiparsky 2001, Holmberg 2010).

a. zero subject

Täällä _ voi joskus nähdä siilin /*siili.

Here-ADE — can-3SG sometimes see hedgehog-ACC/*hedgehog-NOM

'Here one can sometimes see a hedgehog.'

b. overt subject

Jussi näki siilin $/ *$ siili.

Jussi-NOM see-PST-3SG hedgehog-ACC /*hedgehog-NOM

'Jussi saw a hedgehog'

c. (impersonal) passive

Täällä nähtiin siili /*siilin.

Here-ADE see-PASS.PST hedgehog-NOM/*hedgehog-ACC

'A hedgehog was seen here.'

d. imperative

Etsi siili $/ *$ siilin!

Find-IMP hedgehog-NOM/hedgehog-ACC

'Find a hedgehog!' 
Thus, the zero person syntactically realized and patterns like overt arguments for purposes of case assignment (see also Anttila \& Kim 2017, Poole 2015, i.a. on case in Finnish).

2.2 MORPHOSYNTACTIC PERSON AND NUMBER FEATURES. What about the person and number features of the zero? The zero person occurs with third person singular agreement on the verb (1). However, as this is the default verb agreement pattern in Finnish, this is not decisive evidence. Clearer evidence for the person features of the zero - as well as the claim that it is syntactically realized - comes from the fact that the zero can bind third person reflexive anaphors and possessive suffixes (4a,b) (e.g. Hakulinen \& Karttunen 1973, Vainikka 1989, Kaiser \& Vihman 2006). As regards number, adjective agreement (4c) shows that the zero person triggers singular agreement (Vilkuna 1996). The unacceptability of reciprocal pronouns confirms this (ex.4d). ${ }^{2}((4 \mathrm{~d})$ is from the descriptive grammar of Finnish by Hakulinen et al. (2004). I refer to this by its acronym, ISK, 'iso suomen kielioppi,' lit. 'the big Finnish grammar.')
a. Jos
arvostaa itseään
ja omaa
elämäänsä... $\left(\mathrm{www}^{3}\right)$
If _ value-3SG
SELF-PAR-3PX and own-PAR life-PAR-3PX...
'If one values oneself and one's own life and wants to save time...
b. Täällähän _ _ kastelee kenkänsä. (Vilkuna 1996)
Here-ADE-CL — soak-3SG shoes-3PX
'One soaks one's shows here/One gets one's shoes wet here.'
c. Jos _ ei ole tarpeeksi hieno/*hienoja, _ ei
If _ neg-3SG be sufficiently fancy-SG/*fancy-PL, _ neg-3SG get in.
'If one is not sufficiently fancy, one doesn't get in.'
d. *Jos_lyö toisiaan... (ISK)
If _ hit-3SG each-other...
'If one/you hit each other...'

3. Finnish 'zero person' generic construction: Semantic properties. The zero person is a syntactically present, singular, third-person element. In this section we review the semantic properties of the zero. Recall that the zero person has a generic meaning similar to English one and generic you, and is unacceptable in episodic, agentive main clauses (1). Building on Malamud (2012)'s work on the featural properties of impersonal pronouns, I assume that the Finnish zero person involves the feature [gn] (generic) (see also Moltmann 2006, 2010 on English one). In what follows, we consider other semantic properties of the zero person.

3.1 HUMAN, DISTRIBUTIVE REFERENCE. The zero person is construed as referring to humans (Hakulinen \& Karttunen 1973), and usually receives a distributive interpretation (e.g. Löflund 1989). As regards humanness: (5a) can be used to express the sentiment that a human being would freeze here, not water puddles or lakes freeze. Similarly, $(5 \mathrm{~b})$ can be used to state that a human is likely to fall over, not an object like a fence. This is similar to generic one. As regards distributivity: (5c), from Löflund (1998:152), asks about the number of bruises that a generic person receives at a concert in Kaivopuisto (aka Kaivari), not about the total number of bruises

\footnotetext{
${ }^{2}$ Interestingly, when it comes to semantic number, in some contexts the zero person occurs with expressions like 'together' which make reference to semantic plurality (ex.i) and are unacceptable with clearly singular subjects. (Relatedly, see Malamud 2012 and Cabredo-Hoffher 2004 for conflicting evidence on the number properties of German man.) This is an interesting area for future work, but not crucial for the claims being made here.

(i) Ihanaa kun __ saa taas olla yhdessä (ISK, p.1286)

Wonderful that _ can-3SG again to-be together 'It's wonderful that one can be together again.'

${ }^{3}$ Example from a web forum discussion at www.fillarifoorumi.fi/forum
} 
collectively received by everyone at the concert (in contrast to the Finnish impersonal passive which evokes the collective interpretation, as noted by Löflund 1998:152).

a. Täällähän _ jäätyy! (ISK)

Here-CL - freeze-3SG

'One freezes here/it's freezing here!'

b. Näin tuulisena päivänä _ voi kaatua. (Hakulinen \& Karttunen 1973)

Such windy-ESS day-ESS — can-3SG fall

'One can fall over on such a windy day'

c. Kuinka monta mustelmaa saa esimerkiksi

How many-PAR bruise-PAR get-3SG for-example

Kaivarin konsertissa joka kerta?

Kaivari-GEN concert-INE every time-PAR?

'How many bruises does one get, for example, at a Kaivari concert every time?'

3.2 SPEAKER AND ADDRESSEE INCLUSION. Crosslinguistically, generic constructions (6a) typically allow for speaker inclusion, in contrast to arbitrary impersonal constructions (6b, examples from Sigurdsson \& Egerland 2009). In fact, as we will see later, Moltmann (2010) argues that generic one in English involves a special kind of first-person oriented genericity. In line with this generalization, prior research on Finnish suggests that in conversational contexts, the zero person often functions as a device to refer more or less indirectly to the speaker and/or the addressee (e.g. Laitinen 1995, 2006, Hakulinen 1987), although this is not required (e.g. Hakulinen 1987). This is exemplified in (7a,b). (7a) is addressee-oriented: It conveys information to the addressee(s) about being allowed to bring one's own sausages. (7b) is speaker-oriented and is interpreted as the speaker making a comment that applies to him/herself. Crucially, as will become apparent in Sections 4 and 5, not all Finnish zero person constructions 'refer to' the speaker and/or addressee equally directly (cf. (1)). As we will see below, word order plays a crucial role here (see also Laitinen 1992, 1995, 2006). ${ }^{4}$

(6) a. To find the station you/one first turn to the right (or at least I always do).

b. They are on strike in the hotel (\# or at least I am).

(7) a. addressee-oriented:

_ Saa ottaa mukaan omat makkarat may-3SG bring along own-PL sausage-PL

'One/you can bring along your own sausages' (facebook announcement)

b. speaker-oriented: Pitäisi lähteä kotiin. (Laitinen 1995)

\footnotetext{
${ }^{4}$ Most of the zero person examples discussed in this paper involve zero persons that, if replaced with an overt element, would be nominative. I also include some constructions with so-called genitive subjects, such as ex(7b). Genitive subjects occur, for example, with necessive verbs such as täytyä (must, have to), pitää (have to, should), tarvita (need to). With the necessive verb in (7b), an overt 'subject' would be genitive and does not trigger agreement with the finite necessive verb (see Laitinen 1992), although it is the subject of the infinitival verb 'go' (see also Leino 2015, Jaakola 2004 on genitive subjects in Finnish necessive constructions). Despite the lack of subject-verb agreement, Sands \& Campbell (2001) claim that the genitive is the canonical case for subjects of nonfinite clauses in Finnish and Leino (2015) similarly concludes that genitive subjects are "quite ordinary and typical subjects" (p.248), and also points out that genitive subjects can trigger possessive suffix agreement in a way that closely resembles person agreement. Furthermore, as Laitinen (1992) shows, in some dialects of Finnish, subjects of necessive verbs trigger verb agreement and/or can be in nominative case. Thus, I assume that genitive subjects can be grouped together with nominative subjects, for purposes of investigating zero person constructions.
} 


\section{should-COND-3SG go home-ILL \\ 'one/you ( I) should go home'}

3.3 SHIFTING UNDER ATTITUDE VERBS. English generic one, when embedded under attitude verbs, shifts away from the speaker to the subject of the attitude verb (e.g. Moltmann 2006, see also Malamud 2012). Compare (8a) and (8b). While (8a) is most naturally interpreted as conveying a belief held by the speaker, this changes with the addition of an attitude verb: in (8b), it is Hans (not the speaker) holds the belief that one needs a passport to travel to France. Given such examples, Malamud (2012) analyzes English one having logophoric de se semantics - which she encodes as a [se] feature (cf. Anand \& Nevins 2004): In main clauses, a pronoun with the [se] feature points to the speaker, and when embedded under an attitude verb, it shifts to the attitude holder. (See Malamud 2012:31-32 for evidence that one is a de se pronoun but not a shifting indexical.) The Finnish zero person patterns similarly: In (8c), where the zero is embedded under an attitude verb, Pekka is the one who would like to stay here longer, not the speaker.

a. One needs a passport to travel to France. (adapted from Moltmann 2006)

b. Hans believes that one needs a passport to travel to France. (Moltmann 2006)

c. Pekka väittää, että täällä_ viihtyy pitempäänkin

Pekka-NOM claim-3SG, that here-ADE — enjoy-oneself even-longer, mutta minä olen eri mieltä.

But I-NOM be-PRES.1SG different mind-PAR

'Pekka claims that one can enjoy oneself here for a while longer, but I disagree'

3.4 SEMANTIC VERB CONSTRAINTS ON THE ZERO PERSON. A key property of the Finnish zero person is that it is not acceptable in all semantics contexts or with all kinds of verbs. The zero person frequently occurs with verbs that involve some kind of modality (Hakulinen \& Karttunen 1973, Laitinen 1995: 340, Löflund 1998:154), including the modals täytyy (must), saa (be able to / may / be allowed to), voi (be able to / may). In addition, the zero person also occurs with some experiencer verbs like ikävystyä (to become bored) and hermostua (to become annoyed), as well as other verbs with low agentivity and intentionality like nukahtaa (to fall asleep) and mahtua (to fit somewhere). The zero person can also occur with some verbs of perception and emotion (e.g. Jokela 2012). A unified semantic characterization of the verbs which allow the zero person is beyond the scope of the present paper, but broadly speaking, it has been observed that the zero is interpreted as an affected argument, an experiencer, a beneficiary, or a patient - crucially, not agentive (e.g. Laitinen 1995, 2006). This is illustrated by the contrast between (9a), with an experiencer subject, and the unacceptable (9b), with an agentive subject. Laitinen (2006) suggests that the zero person has the proto-patient property of affectedness in the sense of Dowty (1991). Thus, the zero felicitously occurs in contexts where the event expressed by the predicate is not fully under the control of the subject (see also Condoravdi 1989 on the absence of volitional agent in Finnish zero person constructions). ${ }^{5}$
a. Saunan jälkeen _ väsyttää. (Laitinen 1995)
Sauna-GEN after feel-tired-3SG
'You feel tired after the sauna.'
b. *Saunan jälkeen _ _ pukeutuu.
Sauna-GEN after _ get-dressed-3SG

\footnotetext{
${ }^{5}$ Sometimes zeros occur with verbs expressing intentional actions, in which case they tend to occur with adverbs that express an (automatic) reaction.
} 
'You get dressed after the sauna.'

3.5 CONDITIONALS. There is one context in which the above-discussed restrictions are lifted, namely in conditionals. In conditionals (and related constructions), agentive verbs are possible (e.g. Hakulinen \& Karttunen 1973, Laitinen 1995, Löflund 1998:155), as shown in (10). In fact, even agent-oriented adverbials are possible (ex. 10c, Kaiser \& Vihman 2006). The special status of conditionals is not limited to Finnish generic structures: As Moltmann (2006:265) notes, English generic one also has no restrictions in conditionals.
a. Jos _ ei kuuntele eikä If - NEG listen ${ }^{6}$ tee tehtäviä, do exercises, - NEG learn
'If one doesn't listen and do homework, one doesn't learn.'
b. Kotona - voi myös testata home-ESS — can-3SG also test erilaisia - täytettyjä pastoja $\left(\mathrm{www}^{7}\right)$ different-PAR.PL filled-PAR-PL pasta-PL-PAR 'At home one can also test different kinds of filled pasta.'
c. Eri asia on jos _ tahallaan $\left(w_{w w}^{8}\right)$ Different-NOM thing-NOM is if — on-purpose kävelee suoraan latu-urien päällä. Walk-3SG directly skiing-tracks-GEN on-top 'It's a different matter if one walks directly on top of the skiing tracks on purpose.'

So far, we have seen that the Finnish zero is used to express generalizations and is syntactically realized but phonologically null. Morphosyntactically, it is third person and singular, but semantically it can be connected to the speech act participants $(7 \mathrm{a}, \mathrm{b})$ and can shift under attitude verbs, like English generic one. Semantically it is human and typically non-agentive.

3.6 QUANTIFICATIONAL VARIABILITY EFFECTS In this section, I show that the Finnish zero person allows quantificational variability effects (QVE). QVE are a diagnostic for indefiniteness and have been argued to be evidence for the existence of an [arb] feature on English and German impersonal pronouns (Malamud 2012). QVE can be observed with singular and plural indefinites in sentences with quantificational adverbs such as usually, rarely. These quantificational adverbs can target situation or event variables (see Lewis 1975, Berman 1987). In English sentences with indefinites and bare plurals, the adverb can quantify over the variable introduced by the indefinites (e.g. 11a,b,c), which is typically not possible with definites ${ }^{9}(11 \mathrm{~d})$.
a. A cat is usually smart. ${ }^{10}$ ok QVE: Most cats are smart
b. Cats are usually smart. ${ }^{\circ k}$ QVE: Most cats are smart
c. If a cat is Siamese, it is usually smart. ${ }^{\text {ok }}$ QVE: most Siamese cats are smart
d. If the cat is Siamese, it is usually smart. * QVE

\footnotetext{
${ }^{6}$ In negative sentences in the present tense in Finnish, the main verb is a bare inflectional stem without an ending. Negation is an auxiliary and agrees with the subject in person and number.

${ }^{7}$ From www.soneraplaza.fi/ellit/artikkeli

${ }^{8}$ From www.jyvaskyla.fi/kysy/kysymys.php/2267

${ }^{9}$ However, as Malamud (2012) and others have noted, even definites can - under some circumstances - yield QVE effects (see also Endriss \& Hinterwimmer 2006).

${ }^{10}$ In addition to the QVE reading, these kinds of sentences also allow a temporal reading, where a cat is smart at one time but not at another. These readings are not of interest to us here.
} 
e. In those days, \{one/you \} usually lived till 60. ${ }^{\mathrm{ok}} \mathrm{QVE}$ : most people lived to be 60 Intriguingly, QVE also arises with generic you and one (ex.9e, Malamud 2012:36). Malamud (2012:32) captures the availability of QVE effects with one/you by means of an [arb] feature, which introduces a free variable into the denotation, instead of an existentially-quantified indefinite (for details see Malamud 2012:37).

Let us now turn to Finnish. Similar to one/you, the Finnish zero person allows quantificational variability effects (ex.12). (Note that the temporal, non-QVE reading is also available, semantics permitting.) If we follow Malamud (2012)'s analysis of English you/one, this would suggest that the Finnish zero person also has an [arb] feature.
a. Poliisin luotiin kuolee harvoin $\left(\mathrm{www}^{11}\right)$
Police-GEN bullet-ILL _ die-3SG rarely
'One rarely dies from a policeman's bullet.'
${ }^{\text {ok }}$ QVE: Most people do not die from a policeman's bullet
b. tauti on ikävä, mutta siihen kuolee harvoin ( www $^{12}$ )
disease-NOM is unpleasant, but it-ILL _ die-3SG rarely
'The disease is unpleasant but one rarely dies from it'
Ok QVE: Most people who catch this disease do not die from it
c. Suomessa _ pääsee tavallisesti saunaan.
Finland-INE _ get-to-go-3SG usually sauna-ILL
'In Finland you/one usually gets to go to the sauna'
${ }^{\mathrm{Ok}}$ QVE: Most people who visit Finland / who live in Finland get to go to the sauna
d. Jos _ on fiksu, _ on tavallisesti myös tyytyväinen siitä.
If _ is smart, _ is usually also satisfied/pleased it-ELA.
'If one/you are smart, you are usually also pleased with that.'

4. Word order properties. Before considering the word order properties of zero person constructions, let us briefly review the basics of word order in Finnish. Finnish has rich case marking and very flexible word order (e.g. Karttunen \& Kay 1985, Vilkuna 1989, 1996, Vainikka 1989, Holmberg \& Nikanne 2002, Holmberg et al. 1993, Mitchell 1991, Kaiser 2006). The canonical order is SVO, but all possible orders of these elements have been argued to be acceptable in an appropriate context. Generally speaking, contrastive elements (regardless of whether they are new or given information) occur in the left periphery (CP domain), and topical elements occur in the IP domain ${ }^{13}$ (e.g. Vilkuna 1989).

Crucially, according to Holmberg \& Nikanne (2002), the Finnish variety of the EPP is topicality-based, and can be satisfied by both subject and non-subject topics in spec-FP (where F stands for Finite). Arguments have a [+/-Foc] feature, and [-Foc] arguments (topics) are attracted to the head F, by the presence of an EPP-feature on F (Holmberg \& Nikanne 2002:79). [+Foc] marks the 'information focus' of the sentence in the sense of Vallduví and Engdahl (1996) and [Foc] marks an argument as belonging to the ground/old information. [-Foc] is checked by a feature of the head F, and [+Foc] arguments stay lower in the tree. When a sentence contains multiple elements with a [-Foc] feature, only one of these needs to move overtly to the spec of

\footnotetext{
${ }^{11}$ From https://suomenkuvalehti.fi/jutut/kotimaa/poliisin-luotiin-kuolee-harvoin-oulun-tapaus-neljas-2000-luvulla/.

${ }^{12}$ From http://www.lehtiluukku.fi/pub?id=8249.

${ }^{13}$ Holmberg et al. (1993), Holmberg \& Nikanne (2002) and Holmberg $(2005,2010)$ provide more detailed discussions of the landing site for topical [-foc] elements.
} 
FP. These ideas have been revised and updated by Holmberg $(2005,2010)$, but - simplifying somewhat - the original idea is that Finnish has a topicality-based EPP, which requires a (subject or a non-subject) topic in the specifier of FP, revised to be TP in Holmberg's subsequent work.

4.1 CAN ZERO-PERSON SENTENCES NOT BE VERB INITIAL? Holmberg (2010) points out that the first position of zero person sentences cannot be empty and needs to be filled with an overt element. A zero person construction with a sentence-initial locative (13a) is acceptable, in contrast to a zero person sentence where no overt element precedes the verb (13b). Insertion of an expletive also yields an acceptable sentence (ex.13c); I return to this in Section 7. A referential null pronoun (ex.11d, with first-person pro-drop) is fine, indicating that the problem with (13b) is not simply due to lack of phonological material.
a. Suomessa _ joutuu usein saunaan. (adapted from Laitinen 2006)
Finland-INE _ end-up-3SG often sauna-ILL
'In Finland you/one/I often end up in sauna'
b. *_ joutuu usein saunaan Suomessa ${ }^{14}$
c. Sitä _ joutuu usein saunaan Suomessa.
It-PAR — end-up-3SG often sauna-ILL Finland-INE
'In Finland you/one/I often end up in sauna'
d. Joudun usein saunaan Suomessa [referential 1st-person pro-drop]
(I) end-up-1SG often sauna-ILL Finland-INE
'I often end up in the sauna in Finland.'

Why is a verb-initial zero person sentences unacceptable, when a verb-initial sentence with a referential null pronoun is fine? According to Holmberg (2010), the unacceptability of sentences like (13b) is due to the fact that generic zeros cannot satisfy the Finnish EPP - in contrast to topical elements such as overt subjects, objects, locatives, null referential pronouns, and 'lastresort' expletives. ${ }^{15}$ More specifically, Holmberg (2010) proposes that generic zeros cannot satisfy the EPP because their features are a subset of the features of T. Thus, he moves away from a purely topicality-based, information-structurally motivated construal of the EPP. In what follows, I present some word order data that poses challenges for his analysis, and I investigate how far we can push the idea of a topically-based EPP for Finnish. Is it possible to maintain a unified view of the Finnish EPP as being motivated by information-structural considerations?

4.2 VERB INITIAL ZERO-PERSON SENTENCES. Holmberg's observations are challenged by examples like $(7 \mathrm{a}, \mathrm{b}, 14)$. These are verb-initial, yet grammatical, zero-subject sentences (Laitinen 2006). ${ }^{16}$ Note that even here, a non-subject element can optionally be fronted (14d).

a. _ Täytyy harjata hampaat. (Laitinen 2006)

\footnotetext{
${ }^{14}$ This sentence improves if it is uttered in a corrective or contrastive context, similar to the contexts that license verb-initial orders in Finnish non-zero-person sentences (e.g. Vilkuna 1989). In these sentences, the verb is analyzed as having raised to the CP domain, and thus the sentence does not necessarily have an empty spec-TP/FP. In the present paper, when considering the acceptability of verb-initial zero person sentences, we put aside these kinds of contrastive/corrective readings, and focus on sentences where the verb has not raised to the spec-CP domain.

${ }^{15}$ Holmberg notes:"In fact, if the EPP strictly called for a topic, we wouldn't expect an expletive to be able to check the EPP. A closer approximation to the truth is that the subject may check the EPP even if it is not referential, but, for example a quantified NP, while non-subjects have to be referential and interpretable as topics, to check the EPP."

${ }^{16}$ Holmberg (2010, note 16) also acknowledges the existence of verb-initial (and auxiliary-initial) zero person main clauses, but proposes no analysis for why they would be exceptions to the Finnish EPP that he proposes.
} 
must-3SG brush teeth

'One/I/you must brush one's/my/your teeth'

b. _ Ei saa tulla sisään kengät jalassa. (Laitinen 2006).

NEG-3SG may come in shoes foot-INE

'You may not come in with shoes on' / 'Don't come in with your shoes on!'

c. P_ Piti lähteä töihin. (Laitinen 1992:146).

must-3SG-PAST go work-PL-ILL

' $\overline{\mathrm{One}} / \mathrm{I}$ had to go to work.'

d. Hampaat _ täytyy harjata

teeth must-3SG brush

'One/I/you must brush one's/my/your teeth'

Why is the EPP satisfied in $(7,14)$, but not (13b)? Laitinen (2006) notes that "many examples do not contain any preverbal elements" (p.215) and that in these "verb-initial clauses, the zero is usually interpreted to be one of the specific speech act participants" (Laitinen 2006:215), i.e. the speaker or the addressee. ${ }^{17}$ Thus, verb-initial zero person sentences are not always unacceptable and do not always violate the Finnish EPP. Why is this? I propose an answer that builds on Laitinen's (2006) observation regarding speech act participants. My analysis builds on Moltmann $(2006,2010)$ and Malamud (2012), so I review their claims in the following sections.

5. Moltmann's theory. The first part of my answer builds on Moltmann's $(2006,2010)$ work on English generic one. She argues that one "involves 'generic simulation', roughly 'putting oneself into the shoes of anyone meeting relevant conditions" "(Moltmann 2006:257). She observes that in sentences like (15), one is rooted in first-person experience: (15a) expresses the speaker's own experience and makes a generalization, whereas (15b) makes a generalization but does "not serve as an immediate expression of the speaker's own experience" (Moltmann 2006:258).

(15) a. One can see the picture from the entrance.

b. $\{$ People/A typical person $\}$ can see the picture from the entrance.

Moltmann proposes that there are two semantic strategies that license generic one, ${ }^{18}$ which she terms (i) inference from the first person and (ii) inference to the first person. I will sometimes refer to these as Strategy \#1 and Strategy \#2, respectively. (15a) is an example of inference from the first person: It conveys the speaker's own experience, which the speaker knows/assumes to be generalizable to other people. ${ }^{19}$ Thus, a sentence like (15a) provides a generalization as well as a description of a first-person state/experience. The connection to the first person is further illustrated by the contrast between (16a) and (16b): In (16a), it suffices for John to have this experience but in (16b), John needs to confirm that other people can also see the picture.

(16) a. John found out that one can see the picture from the entrance.

b. John found out that people can see the picture from the entrance.

\footnotetext{
${ }^{17}$ Relatedly, Yli-Vakkuri (1986:113-115) discusses examples from different regional dialects of Finnish where a singular third-person verb occurs with a zero subject and has an addressee-referring function. Yli-Vakkuri notes that Latvala (1895:51) already commented on what he viewed as the strange property of being both impersonal and in some sense imperative at the same time - in other words, this phenomenon is not a new one in Finnish.

${ }^{18}$ Moltmann (2006) discusses three strategies: (i) Inference from the first person, (ii) inference to the first person and (iii) Inference from the simulating self. Moltmann (2010) only discusses (i) and (ii), and I do the same.

${ }^{19}$ These sentences are also ok if the speaker has not had the experience herself (perhaps is blind?), but the speaker puts herself in the position of 'the normal person' who can see the picture, via simulation (Moltmann 2006: 266)..
} 
Moltmann (2006) suggests that the strategy of 'inference from the first person' involves generic simulation, ${ }^{20}$ such that "a property is attributed to anyone in the relevant class on the basis of the speaker's attributing that property as if to himself, while abstracting from the peculiarities of his own situation" (Moltmann 2006: 269).

The second strategy licensing generic one, according to Moltmann is 'inference to the first person:' "The speaker presents an internalized but already established generalization, a law, general requirement, or general recommendation" (Moltmann 2006:274), which does not rely on a specific experience of the speaker. As (17a-c) show, this often involves deontic modality:

a. One is not allowed to enter the room. (Moltmann 2010: 469)

b. One should not lie. (Moltmann 2010: 469)

c. One should be respectful toward the elderly. (Moltmann 2010: 469)

She notes that these kinds of generalizations are "presented with the intention to be at least potentially applied in a first-person way by whoever accepts the sentence, in particular the addressee" (Moltmann 2010: 468). The observation that the sentences are intended to the applied to the addressee is also illustrated by $(18 \mathrm{a}, \mathrm{b})$. To signal to someone that they should not enter a particular room, a speaker is more likely to use (a) than (b (Moltmann 2006:275).

a. One is not allowed to enter the room.

b. No one is allowed to enter the room.

In sum, Moltmann argues that one is licensed by (i) Inference from the first person (Strategy \#1) or (ii) Inference to the first person (Strategy \#2). Inference from the person involves first-person experience (or simulation thereof) and generalization to others, whereas inference to the first person involves an established generalization, law or recommendation that is intended to apply to whoever accepts the sentence, e.g. the addressee (and typically presumably also the speaker).

\subsection{APPLYING MOLTMANN’S INSIGHTS TO FINNISH ZERO PERSON SENTENCES. Applying} Moltmann's strategies to Finnish, we see that 'Inference from the first person' (Strategy \#1) captures examples like (13), and 'Inference to the first person' (Strategy \#2) is relevant precisely for the verb-initial zero-subject sentences $($ e.g. 7,14$)$ that appear to violate the Finnish EPP.

More specifically, I claim that, first, in Finnish, verb-initial zero person sentences involve 'Inference to the first person', though not all sentences that use inference to the first person are verb initial (14d). Second, non-verb-initial zero person sentences can involve 'Inference from the first person or 'Inference to the first person.' Thus, the picture that that emerges is that when a zero person sentence is verb-initial ${ }^{21}$ - i.e., appears to violate the Finnish version of the EPP - it also involves 'Inference to the first person.' Non-verb-initial zero person sentences are compatible with both of the inference strategies proposed by Moltmann.

This brings us to the key question: Since verb-initial zero person sentences like $(7,14)$ are acceptable, does this mean that (i) the EPP does not apply to Finnish, contra Holmberg (2010) and others, or that (ii) the EPP does hold, and in these sentences it is somehow satisfied despite the lack of an overt preverbal element?

In what follows, I will argue for the second option, and see whether we can maintain the idea that Finnish has a uniform, information-structure related EPP - even when faced with verb-

\footnotetext{
${ }^{20}$ Simulation refers to the idea that "third-person ascriptions of attitudes and explanations and predictions of actions are based on first-person ascriptions: on the basis of 'putting oneself in the other person's shoes', that is, of pretending to be that person or taking the other person's point of view" (Moltmann 2006:269).

${ }^{21}$ In a context where the verb has not raised to the CP domain for reasons of contrast (see note 14).
} 
initial zero person sentences that seem to have nothing satisfying the EPP. Intuitively, the proposal is that in zero person sentences that involve inference to the first person (Strategy \#2), the zero person makes reference to the speech act participants (see Laitinen 2006, Moltmann 2006), and this renders zero more topical and thus able to satisfy the EPP. This yields verb-initial zero person sentences. In contrast, in zero person sentences that involve inference from the first person (Stragey \#1), the zero is highly generic, and not sufficiently topical to satisfy EPP. Thus, these sentences need an overt preverbal element to check the EPP.

Can these intuitions be formalized? In the next section, I build on work by Malamud (2012), which I already alluded to earlier, in an initial attempt to do this.

6. Formalizing the two kinds of zeros. In her work on impersonal pronouns in English and German, Malamud (2012) builds on Kratzer (2009). Malamud (2012)'s analysis of English you/one and German man addresses the tension that these forms exhibit in being both generic and speaker/hearer-associated (indexical). She proposes that (i) English one is built out of the features [se], [arb], [human] and [gn] and that (ii) English you is built from the features [2nd], [arb], and [gn]. As mentioned in Section 3, [se] captures the speaker-oriented nature of one. Correspondingly, [2nd] captures the addressee-oriented nature of you. On the relevant reading, both of these pronouns are generic - hence the feature [gn] - and both exhibit quantification variability effects, which Malamud interprets as evidence that they introduce free variable into the denotation - hence the impersonal-building feature [arb] (see Section 3). My summary cannot capture the details of Malamud (2012); the reader is referred to her paper for details.

6.1 FEATURES OF ZEROS IN VERB-INITIAL SENTENCES. In the preceding section, I argued that verbinitial zero person sentences in Finnish are a case of Moltmann's 'inference to the first person' (Strategy \#2), which involves an "already established generalization, a law, general requirement or general recommendation" (Moltmann 2006:274) that applies to the speaker and the addressee. I further suggested that in these sentences, the Finnish variant of the EPP is satisfied thanks to the zero being sufficiently topical or concrete to check the EPP. We are now in a position to formulate this claim more explicitly, using some of the features posited by Malamud (2012):

I assume that in contexts involving 'inference to the first person' (Strategy \#2), the Finnish zero subject is built out of the features [arb], uninterpretable [gn] and, crucially, that speakeroriented zeros have the speaker-anchored [se] feature ('de se') while addressee-oriented zeros have the addressee-anchored [2nd] feature. This is very much in line with Malamud's analysis of generic you and one respectively, which posits that one is built out of [se], [arb], [human] and [gn], and impersonal you out of [2nd], [arb] and [gn]. In Finnish, let us call both speakeranchored and addressee-anchored zeros Type 2 zeros, given that - according to my proposal they involve Moltmann's Strategy \#2.

I propose an extension to the Finnish topicality-oriented EPP (broadly speaking, the need to have something topical in spec-TP/FP), namely that it is satisfied not only (i) by [-foc] elements - as already proposed by Holmberg \& Nikanne (2002) but also (ii) by elements that have [se] or [2nd] features, e.g. Type 2 zeros. This successfully derives the word-order patterns in $(7,14)$ showing that verb-initial zero person sentences are acceptable with Type 2 zeros.

6.2 FEATURES OF ZEROS IN NON-VERB-INITIAL SENTENCES. In Section 5, I claimed that non-verb initial zero person sentences in Finnish can involve either 'inference from the first person' (Strategy \#1) or 'Inference to the first person' (Strategy \#2). How does this follow from the features of the zeros? We already considered Type 2 zeros above. I further posit that in cases of 'Inference from the first person' (Strategy \#1), the zero is built out of [gn] and [arb], but has no 
[se] or [2nd] features. Speaker- or addressee-orientation may be pragmatically inferred in some contexts but, under this view, is not part of the semantics of these zeros. Let us call these Type 1 zeros. The two kinds of zeros are summarized in (19). My proposal thus posits two types of zeros with partially overlapping features (cf. Kratzer 1997 on two kinds of German man.)

As a consequence of their featural make-up, Type 1 zeros cannot satisfy the EPP, and thus verb-initial zero person sentences are unacceptable with Type 1 zeros: In sentences with Type 1 zeros, a topical [-Foc] element needs to raise to spec-TP to satisfy the EPP. This successfully derives the word order patterns in examples like (13).

(19) a. Type 1 zero: Inference from the first person [gn], [arb], [human], [se] or [2nd] b. Type 2 zeros: Inference to the first person [gn], [arb], [human]

However, what about examples like (14d), which appear to involve Type 2 zeros but are not verb initial - in other words, have an overt [-foc] element in spec-TP? One way of capturing this pattern is simply to say that the [-foc] element which has raised to spec-TP checks the EPP in these cases. As a consequence, the Type 2 zero can stay lower in the tree - something that Holmberg \& Nikanne (2002) argue that 'regular' Finnish subjects can do anyway if the higher specifier is already filled. Under this view, the Finnish EPP feature is such that it can be checked either by [-Foc] (in non-verb-initial zero person sentences) or by [se] and [2nd] (in verb-initial zero person sentences with Type 2 zeros). Perhaps what this boils down to is that [se] and [2nd] are also [-Foc] in Finnish - in other words, convey topical, non-focused information.

Furthermore, Holmberg \& Nikanne (2002) already explain that in sentences with multiple [Foc]-marked elements, only one of them moves overtly. Thus, recasting my proposed analysis in terms of [-Foc] instead of [se] and [2nd] does not appear to have strong negative consequences for the central claims being made in this paper. However, in the next section I present some evidence in favor of maintaining a [se] feature. In the end, the key intuition is simply that 'inference to the first person' involves a kind of zero that makes reference to the speech act participants, and this has consequences for its ability to satisfy the EPP.

7. Additional evidence: Expletive sitä and proximal tässä. In this section I suggest that additional evidence for my claim that the Finnish version of the EPP is sensitive not only to [foc] but also to features referring to the speech-act participants, namely [se] and [2nd] - comes from the expletive particle sitä (it-PART) and the proximal locative tässä (here-INESS).

\subsection{EXPLETIVE PARTICLE SITÄ: AN INDICATION OF SPEAKER-ANCHORED AFFECTIVE MEANING.} According to Holmberg \& Nikanne (2002), the expletive sitä (it-PART) is a pure expletive that simply functions to check the EPP feature in a formal way that does not make reference to the topicality-related property discussed earlier. However, in this section I propose and pursue the idea that use of sitä in zero person sentences is sensitive to information-structural properties. Broadly speaking, I suggest that sitä provides further evidence for the claim that the Finnish EPP can be satisfied by the speaker-oriented feature [se], which I suggested occurs with speakeranchored zeros involving 'inference to the first person'.

First, it is worth noting that variants with and without sitä can differ pragmatically, which is unexpected if sitä is purely expletive as assumed by Holmberg \& Nikanne (2002), Holmberg (2010) and Greco et al. (2018). Consider (20) from Hakulinen (1975):

a. No expletive:

$$
\begin{aligned}
& \text { Kaikkeen } \\
& \text { Everything-ILL__ } \_ \text {kyllästyy. (Hak } \\
& \text { get-bored-3SG }
\end{aligned}
$$


'One gets bored of everything.'

b. With expletive:

Sitä $\quad$ kyllästyy kaikkeen. (Hakulinen 1975)
It-PAR $\quad$ get-bored-3SG everything-ILL
Possible paraphrase: '(In my personal experience,) one gets bored of everything
(and I am bored of everything)'

Hakulinen (1975) notes 'that use of sitä indicates "the speaker has [relevant] personal experience (...or...) is referring to himself” (my translation). Relatedly, ISK notes that sentence-initial sitä in zero person sentences signals that the sentence conveys the speaker's experience (ISK, section 827). A corpus example from ISK is provided in (21), where use of sitä signals that the speaker, Marina, is speaking based on her own experience:

(21) Maanantai-illan Marina rentoutui kavereidensa kanssa pelaamalla lentopalloa.

'On Monday night Marina relaxes with her friends by playing volleyball.

"Sitä _ lihoo liikaa, jos _ vain lukee ja syö suklaata.",

"It-PAR _ gains-weight too-much, if _ only read-3SG and eat-3SG chocolate-PAR"

Possible paraphrase: 'In my personal experience, one gains too much weight if one just reads and eats chocolate'

A similar phenomenon exists in Dominican Spanish, where the expletive ello has been claimed to convey speaker-related meaning (Greco et al. 2018). Following Hakulinen (1975), I argue that in Finnish sitä in sentence-initial position in zero-subject sentences signals to the addressee that the zero is associated with the speaker. More speculatively, could we assume that - given the claims that sitä expresses speaker-oriented affective meaning - sitä has the speaker-oriented [se] feature and can thus satisfy the EPP? In this kind of situation, similar to the non-verb-initial zero person sentences involving Type 2 zeros and 'inference to the first person' discussed above, the overt sit $\ddot{a}$ would check the EPP feature, instead of the Type 2 zero doing so. The zero, which we know is syntactically active, would stay lower in the tree (similar to 14d). As mentioned, this is something that overt subjects in Finnish can do if the higher specifier is filled (Holmberg \& Nikanne 2002).

7.2 'LOCATIVE' EXPLETIVE TÄSSÄ. Additional evidence that elements other than the zero can carry speaker-related features comes from the locative particle täss $\ddot{a}$ (here-INESS), which also satisfies the EPP in zero person sentences. Hakulinen (1987) calls it a 'proximity adverbial.'

a. tässä _ unohtaa koko pahuksen sauhuttelun.

Here-INE — forget-3SG whole darn-ACC smoking-ACC

'One forgets ( $\sim$ I forget) about smoking' (www discussion about quitting smoking)

It is important to note that tässä does not necessarily refer to the speaker's location (e.g. ISK). In (22), for example, that would require a different case ending (täällä, here-ADESS). Instead, the intuition is that $t \ddot{a} s s \ddot{a}$ signals that the utterance applies especially to the speaker, like sitä (e.g. see discussion in ISK, Jokela 2012; see also Hakulinen 1987). Thus, this may be another case of an affective element satisfying the EPP due to a speaker-anchored, logophoric [se] feature.

8. Conclusions. In this paper, I suggest that seemingly puzzling word-order properties of the Finnish generic zero-person construction can be explained if we acknowledge the previously largely overlooked relevance of speech-act participants for the Finnish EPP. Extending the analysis proposed by Malamud (2012) for English and German, I suggest that the Finnish zero person is built from the features [arb], [gn] and [se]/[2nd], and propose a refinement to the 
topicality-based EPP in Finnish that can be used to explain unexpected word order patterns of the zero person construction. This work draws new connections between reference to speech-act participants (in particular speaker-related meaning) and word order constraints.

\section{References}

Anand, Pranav \& Andrew Nevins. 2004. Shifty operators in changing contexts: Indexicals in Zazaki and Save. Proceedings of Semantics and Linguistic Theory (SALT) 14. 20-37. https://doi.org/10.3765/salt.v14i0.2913.

Anttila, Arto \& Jong-Bok Kim. 2017. Locality and variation in Finnish structural case. Natural Language \& Linguistic Theory 35(3). 581-634. https://doi.org/10.1007/s11049-016-9352-x.

Berman, Steve. 1987. Situation-based semantics for adverbs of quantification. In John Blevins \& Anne Vainikka (eds.), UMass Occasional Papers in Linguistics 12. Amherst: GLSA.

Cabredo-Hofherr, Patricia. 2004. Impersonal pronouns in Somali, French and German. Paper presented at Syntax of the World's Languages (SWL 1), Leipzig, Germany.

Condoravdi, Cleo. 1989. Indefinite and generic pronouns. Proceedings of WCCFL 8. 71-84.

Dowty, David. 1991. Thematic proto-roles and argument selection. Language 67. 547-619. https://doi.org/10.1353/lan.1991.0021.

Endriss, Cornelia \& Stefan Hinterwimmer. 2006. The non-uniformity of quantificational variability effects: A comparison of singular indefinites, bare plurals, and plural definites. Belgian Journal of Linguistics 19. 93-120.

Greco, Ciro, Liliane Haegeman \&Trang Phan. 2018. Expletives and speaker-related meaning. In Michelle Sheehan \& Laura R. Bailey (eds.), Order and structure in syntax II: Subjecthood and argument structure. 69-93. Berlin: Language Science Press.

Hakulinen, Auli. 1975. Suomen sitä: pragmatiikan heijastuma syntaksissa. Sananjalka 17. $24-41$. Hakulinen, Auli. 1987. Avoiding personal reference in Finnish. In Jef Verschueren \& Marcella Bertucelli-Papi (eds.), The pragmatic perspective. 141-153. Amsterdam: John Benjamins.

Hakulinen, Auli \& Lauri Karttunen, 1973. Missing persons: On generic sentences in Finnish. Proceedings of the Chicago Linguistic Society (CLS) 9. 157-71.

Holmberg, Anders. 2010. The null generic subject pronoun in Finnish: A case of incorporation in T. In Theresa Biberauer, Anders Holmberg, Ian Roberts \& Michelle Sheehan (eds.), Parametric variation: Null subjects in minimalist theory. 200-230. Cambridge: Cambridge University Press.

Holmberg, Anders, Urpo Nikanne, Irmeli Oraviita, Hannu Reime \& Trond Trosterud. 1993. The structure of INFL and the finite clause in Finnish. In Anders Holmberg \& Urpo Nikanne (eds.), Case and other functional categories in Finnish syntax. 177-206. Berlin: Mouton de Gruyter.

Holmberg, Anders \& Urpo Nikanne. 2002. Expletives, subjects and topics in Finnish. In Peter Svenonius (ed.), Subjects, expletives, and the EPP. 71-105. Oxford University Press.

ISK = Hakulinen, Auli, Maria Vilkuna, Riitta Korhonen, Vesa Koivisto, Tarja Riitta Heinonen \& Irja Alho. 2004. Iso suomen kielioppi. Helsinki: Suomalaisen Kirjallisuuden Seura.

Jaakola, Minna. 2004. Suomen genetiivi. Helsinki: Suomalaisen Kirjallisuuden Seura.

Jokela, Hanna. 2012. Nollapersoonalause suomessa ja virossa. Tutkimus kirjoitetun kielen aineistosta. Turku, Finland: University of Turku dissertation.

Kaiser, Elsi. 2006. Negation and the left periphery in Finnish. Lingua 116(3). 314-350. https://doi.org/10.1016/j.lingua.2004.08.008.

Kaiser, Elsi \& Virve-Anneli Vihman. 2006. Invisible arguments: Effects of demotion in Estonian 
and Finnish. In Torgrim Solstad \& Benjamin Lyngfelt (eds.), Demoting the agent: Passive and other voice-related phenomena. 111-141. Amsterdam: John Benjamins.

Karttunen, Lauri \& Martin Kay. 1985. Parsing in a free word order language. In David R.

Dowty, Lauri Karttunen \& Arnold Zwicky (eds.), Natural language parsing. 279-306. Cambridge: Cambridge University Press.

Kiparsky, Paul. 2001. Structural case in Finnish. Lingua 111. 315-376.

https://doi.org/10.1016/S0024-3841(00)00035-8.

Laitinen, Lea. 1992. Välttämättömyys ja persoona. Suomen murteiden nesessiivisten rakenteiden semantiikkaa ja kielioppia. Helsinki: Suomalaisen Kirjallisuuden Seura.

Laitinen, Lea. 1995 Nollapersoona. Virittäjä 99. 337-358.

Laitinen, Lea. 2006. Zero person in Finnish: A grammatical resource for construing human evidence. In Marja-Liisa Helasvuo \& Lyle Campbell (eds.), Grammar from the human perspective: Case, space and person in Finnish. 209-232 Amsterdam: Benjamins.

Latvala, Salu. 1895. Lauseoppillisia havaintoja Luoteis-Satakunnan kansankielestä. Helsinki: Suomalaisen Kirjallisuuden Seura (series Suomi III 12).

Leino, Jaakko. 2015. The syntactic and semantic history of the Finnish genitive subject. In Marja-Liisa Helasvuo \& Tuomas Huumo (eds), Subjects in constructions - canonical and non-canonical. 231-251. Amsterdam: John Benjamins.

Lewis, David K. 1975. Adverbs of quantification. In Edward L. Keenan (ed.), Formal semantics of natural language. 315. Cambridge: Cambridge University Press.

Löflund, Juhani. 1998. Suomen kirjoitetun yleiskielen passiivi. Turku: Åbo Akademis Förlag.

Malamud, Sophia. 2012. Impersonal indexicals: One, you, man, and du. Journal of Comparative Germanic Linguistics 15(1). 148.

Maling, Joan. 1993. Of nominative and accusative: The hierarchical assignment of grammatical case in Finnish. In Anders Holmberg \& Urpo Nikanne (eds.), Case and other functional categories in Finnish syntax, 49-74. Berlin: Mouton de Gruyter.

Mitchell, Erika. 1991. Evidence from Finnish for Pollock's theory of IP. Linguistic Inquiry 22. 373-379. https://www.jstor.org/stable/4178727.

Poole, Ethan. 2015. A Configurational Account of Finnish Case. University of Pennsylvania Working Papers in Linguistics 21(1). Article 26.

Sands, Kristina \& Campbell, Lyle. 2001. Non-canonical subjects and objects in Finnish. In Alexandra Y. Aikhenvald, R. M. W. Dixon \& Masayaki Onishi (eds.), Non-canonical marking of subjects and objects. 251-305. Amsterdam: John Benjamins.

Sigurðsson, Halldór \& Verner Egerland. 2009. Impersonal null subjects in Icelandic and elsewhere. Studia Linguistica 63(1). 158-185.

Timberlake, Alan. 1974. The nominative object in Slavic, Baltic, and West Finnic. Berlin: Otto Sagner.

Vainikka, Anne. 1989. Deriving syntactic representations in Finnish. Amherst, MA: University of Massachusetts dissertation.

Vallduví, Enric \& Elisabet Engdahl. 1996. The linguistic realization of information packaging. Linguistics 34. 459-519.

Vilkuna, Maria.1989. Free word order in Finnish: Its syntax and discourse functions. Helsinki: Suomalaisen Kirjallisuuden Seura.

Vilkuna, Maria. 1992. Referenssi ja määräisyys suomenkielisten tekstien tulkinnassa. Helsinki: Suomalaisen Kirjallisuuden Seura.

Vilkuna, Maria. 1996. Suomen lauseopin perusteet. Helsinki: Edita. 
Yli-Vakkuri, Valma. 1986. Suomen kieliopillisten muotojen toissijainen käyttö. Turku, Finland:

Department of Finnish and General Linguistics at the University of Turku, Finland, vol. 28. 